\title{
POSTING OF WORKERS DIRECTIVE RELOADED
}

\begin{abstract}
In view of levelling the playing field between foreign and local employers in the host country, the European Commission proposed in March 2016 to revise the Posting of Workers Directive (PWD) 96/71/EC. The amended PWD (EU) 2018/957, that was adopted mid-2018, introduces some significant changes in order to combat the shortcomings resulting from the original PWD, strengthening the importance of ensuring fair competition (between local and foreign employers) and improving the protection of workers. In a nutshell, the PWD aims at promoting the principle of equal pay for equal work in the same place, especially by extending the so-called hard nucleus of working conditions and introducing a provision for long-term postings. This new legislation will be implemented throughout the EU as of mid-2020. The following article aims to investigate the extent to which the changes demand national implementation from an Austrian point-of-view; the latter could serve as a guidance.
\end{abstract}

Słowa kluczowe: delegowanie pracowników, zasada równej płacy, wynagrodzenie, dodatki lub zwrot wydatków na pokrycie kosztów podróży, warunki pracy, umowy zbiorowe, pracownicy tymczasowi, egzekwowanie, non-genuine postings

Keywords: posting of workers, equal pay, remuneration, posting allowances, working conditions, collective agreements, temporary agency workers, enforcement, non-genuine postings

ASCJ: 3308, JEL: K 31

\section{Introduction}

This article is dedicated to the amended Posting of Workers Directive (EU) 2018/957 (OJ L 2018/173 of 28 June 2018, p. 16) and aims to investigate the extent to which the changes demand national implementation from an Austrian point-of-view (also: Aubauer, Glowacka 2019). The choice of covered subjects for the present article is reflected in the particular topicality of the subject as well as the significance from an Austrian perspective. 


\section{Development}

The landmark ruling of the ECJ (judgement of the ECJ, Rush Portuguesa, C-113/89) in the case of Rush Portuguesa undoubtedly gave a strong impetus to regulate the posting of workers by a specific Directive 96/71/EC (OJ L 1997/18 of 16 December 1996, p. 1; hereinafter as: Posting of Workers Directive - PWD). The ECJ found that if a company sends its domestic workforce abroad to provide services, the host Member State must not ask the service provider to obtain work permits for the posted workforce. Otherwise, this service provider would be discriminated compared to local competitors established in the host Member State, who do not need to obtain work permits for their local staff. Nevertheless, the ECJ also stated in an obiter dictum that:

[...] community law does not preclude Member States from extending their legislation, or collective labour agreements entered into by both sides of industry, to any person who is employed, even temporarily, within their territory, no matter in which country the employer is established; nor does Community law prohibit Member States from enforcing those rules by appropriate means.

Therefore, the aim of the PWD was to balance out on the one hand the promotion of freedom to provide services and the guarantee of a level playing field for cross-border service providers as well as the protection of posted workers from unfair treatment and the prevention of a low-cost labor pool on the other hand (European Parliament 2018, p. 18). Nowadays, the latter is summarised under the slogan "wage and social dumping control".

In 2014, the Enforcement Directive 2014/67/EU (OJ L 2014/159 of 15 May 2014, p. 11) was adopted in order to ensure uniform implementation, application and enforcement of the PWD, in particular to combat and sanction circumvention practices and improve administrative cooperation. Nonetheless, shortcomings in ensuring the original objectives, namely fair competition and protection of workers, had been identified. It was put forward that the nearly 20-year-old PWD was no longer able to do justice to the developments since 1996 and the specific challenges of the labour market (i.e. escalating pay gaps between Member States, but also increasing legal uncertainty in the light of some regulatory gaps). The European Commission therefore took on the task of promoting the principle of equal pay for equal work in the same place and of tackling unfair practices. Therefore, it submitted a proposal for the targeted revision of the PWD on $8^{\text {th }}$ March 2016 (Risak 2016, p. 306). This was even before the Impact of the Enforcement Directive was known, since Member States were required to implement only by $18^{\text {th }}$ June 2016 (European Economic and Social Committee 2017, p. 83). As a result, the so-called CEE countries (Poland, Slovakia, the Czech Republic, Hungary, etc.) sent a letter to the Commission, criticizing the date of the revision and expressing concern that the principle of equal pay for equal work in the same place would not be compatible with the internal market. On the other hand, Western Member States (including Austria, Germany and France) confirmed their support for the amendment of the PWD (European Commission 2016a, p. 50). 
The Commission's proposal had been discussed for more than one and a half years. In October 2017, both the Employment Committee of the European Parliament and the Council adopted a general approach to the revision of the PWD, which paved the way for the trilogue negotiations between the Council, the European Commission and the European Parliament that were concluded on $19^{\text {th }}$ March 2018. Following a final vote in the European Parliament on $29^{\text {th }}$ May 2018 and its adoption at the EPSCO Council on $21^{\text {st }}$ June 2018, the new PWD (EU) 2018/957 was signed on $28^{\text {th }}$ June 2018 and published on $9^{\text {th }}$ July 2018 in the Official Journal of the EU. Article $3 \$ 1$ requires Member States to adopt and publish the laws, regulations and administrative provisions necessary to comply with this Directive by $30^{\text {th }}$ July 2020 . Until then, the old PWD continues to apply in the version that preceded the amendments introduced by this Directive. The new Directive establishes a balanced framework with regard to the freedom to provide services and the protection of posted workers, which is non-discriminatory, transparent and proportionate while respecting the diversity of national industrial relations (recital 24) (European Committee of the Regions 2017, p. 75). Thus, the Directive seems to anticipate the discussion as to whether the reform is compatible with the freedom to provide services. However, this final assessment is incumbent on the ECJ. ${ }^{1}$

\section{Reform overview}

The PWD is amended in the following points:

- In a new Art. 1 para. 1a - in accordance with Art. 1 para. 2 of the Enforcement Directive - it has been clarified that the PWD in no way affects the exercise of recognised fundamental rights (in particular freedom to strike). ${ }^{2}$

- In Art. 1 para. 3 lit. c, a new subparagraph has been introduced, which establishes provisions for successive postings of temporary agency workers.

- The hard nucleus of working conditions of the host state according to Art. 3 para. 1 is subject to change in connection with remuneration and has been extended by accommodation conditions and reimbursement of expenditure. Fur-

1 This has already been discussed in the literature in the context of the original PWD, although it seems to intervene significantly less in the freedom to provide services than the new version. The protection of workers within the Union has already been considered to be sufficiently ensured by the original PWD, which means that further restrictions on the freedom to provide services cannot be justified, with reference to the overriding reason in the general interest of workers protection, intervene significantly less in the freedom to provide services than the new version. The protection of workers within the Union has already been considered to be sufficiently ensured by the original PWD, which means that further restrictions on the freedom to provide services cannot be justified, with reference to the overriding reason in the general interest of workers protection.

${ }^{2}$ See the Regulation on the exercise of the right to take collective action within the context of the freedom of establishment and the freedom to provide services, COM (2012) 130 final (Monti II), proposed by the Commission and ultimately withdrawn, which should clarify that the right to strike and the freedom to provide services are equal. 
thermore, the restriction of the application of working conditions laid down in collective agreements to works listed in the Annex has been deleted.

- A new Art. 3 para. 1a introduces a provision for long-term postings.

- A new Art. 3 para. $1 \mathrm{~b}$ regulates the mandatory application of the principle of equal treatment in accordance with Art. 5 Temporary Employment Directive.

- The regulation on posting allowances in Art. 3 para. 7 has been extended by a payment obligation and a rule of doubts.

- The restriction of Art. 3 para. 8, according to which only Member States that do not have a system for declaring collective agreements or arbitration awards to be of universal application can apply other collective agreements with a widespread impact, has been deleted.

- The possibility of Art. 3 para. 9 to apply more favourable provisions for temporary agency workers has been adapted to the changes in Art. 3 para. $1 \mathrm{~b}$.

- The derogation of Art. 3 para. 10 with regard to public policy provisions has been adjusted to ensure that working conditions laid down in collective agreements apply to all sectors.

- The provision with regard to cooperation on information pursuant to Art. 4 para. 2 has been extended in such a way that if the competent authority in the sending Member State does not have the information requested by the host Member State, it must obtain this information from other bodies or authorities; otherwise the Commission shall be informed and take appropriate measures.

- There is an intensification of the required measures in case of non-compliance with the PWD and in the case of so-called non-genuine postings.

Finally, the Commission's proposal contained a provision that gave the faculty to Member States to oblige undertakings to subcontract only to undertakings that grant workers certain conditions on remuneration applicable to the contractor, including those resulting from non-universally applicable collective agreements. While the Enforcement Directive determines who can be held liable for wage payment, it does not address the question of what wage a posted worker in a subcontracting chain is entitled to (European Commission 2016a, p. 15). Although this provision did not stand up to the trilogue negotiations, recital 25 provides that Member States should take appropriate measures, in accordance with Art. 12 of Directive 2014/67/EU, to ensure subcontracting liability, in order to tackle abuses in subcontracting situations and in order to protect the rights of posted workers. The Commission has to assess whether further action is needed in this context in a report on the application and implementation of the Directive, which should be completed 5 years after the entry into force of the amending Directive. The same applies to the road transport sector, for which, pending the application of lex specialis, Directive 96/71/EC remains in force (Art. 3 para. 3). 


\section{Significant innovations in detail}

\section{Hard nucleus of terms and conditions of employment}

Directive 96/71/EC limited the minimum terms and conditions of employment to be guaranteed to posted workers to a final catalogue. Especially in view of the court ruling of the ECJ in the case of Laval, it was argued in the literature that the protective provisions enumerated in Art. 3 para. 1 lit. a-g were simultaneously to be considered maximum standards (Kullmann 2015, p. 44). Therefore, a restriction of the freedom to provide services is justified exclusively within the hard nucleus of the PWD. Only the conditions laid down by law, regulation or administrative provision were applied, collective agreements or arbitration awards were only valid for the construction works listed in the Annex, which included all building work relating to the construction, repair, upkeep, alteration or demolition of buildings. Since, in line with the Commission's proposal, the reference to the activities listed in the Annex has been deleted, in the future collective working conditions (see Art. 3 para. 8 new) shall apply to all sectors, as long as they have a broad impact. Regardless of whether they have a system for declaring collective agreements to be of universal application, Member States now have the option of applying other general collective agreements (see Art. 3 para. 8 new). As hitherto, this applies to representative regional or sectoral collective agreements, i.e. those which are generally applicable to all similar undertakings in the geographical area and in the profession or industry concerned or which have been concluded by the most representative employers' and labour organisations at national level and which are applied throughout national territory. Nevertheless, no obligation is put upon those Member States which have no industrial relations model to adopt these agreements (Council of the European Union 2016a, p. 11).

One of the most significant innovations of the new PWD concerns wages to which posted employees are entitled. Granting only the "minimum rates of pay" was mandatory,but has been replaced with the reference to "remuneration". This term is determined by national legislation and / or practice of the host Member State and includes all constituent elements of remuneration rendered mandatory by national law, regulation or administrative provision, or by collective agreements or arbitration awards which have been declared universally applicable or otherwise generally binding in accordance with Art. 3 para. 8. There is a particular focus on the fact that the setting of wages is a matter for the Member States and the social partners alone, and that this principle must not be undermined (see recital 17). Comparing the remuneration of the sending and the host state should be based on the total gross amounts and shall not be broken downinto the constituentelements, which counteracts potential "cherry picking". The identification of the constituent elements of remuneration is only a matter of transparency, which should also make it easier for national authorities to conduct audits and controls (recital 18). Allowances specific to postings that are not to be allocated to the reimbursement to expenditure should also be considered as part of the gross pay (see recital 20). The 
components that make up the remuneration must also be published on the website that has already been set up in accordance with Art. 5 Enforcement Directive.

Apart from that, this cataloguehas been extended by two provisions, beyond the Commission's proposal. Firstly, the conditions for accommodation should also apply to posted workers if the accommodation is provided by the employer to workers who work away from their regular place of work (Art. 3 para. 3 lit. h). ${ }^{3}$ The competent authorities should be able to verify whether the conditions of accommodation for posted workers directly or indirectly provided by the employer comply with the national rules in the host Member State (recital 7). Secondly, the hard nucleus now includes allowances or reimbursement of expenditureto cover travel, board and lodging expenses for posted workers where they have to travel to and from their regular place of work in the host country or are temporarily sent by their employerfrom that regular place of work to another place of work (Art 3 para. 1 lit. i; Council of the European Union 2017, p. 4). According to Art. 3 para. 7 subpar. 2 second sentence, employers are required to reimburse posted workers for expenditure incurred on the account of posting (especially expenditure on travel, board and lodging) in accordance with the national law and/or practice applicable to the employment relationship, with the exception of accommodation in accordance with Art. 3 para. 1 lit. h (Council of the European Union 2018, p. 1). It is for Member States to set rules with regard to the reimbursement of such expenditure (recital 19). Double payment of travel, board and lodging expenses should be avoided (recital 8).

All elements of pay that were previously qualified as a minimum wage are now part of the concept of "remuneration" (Council of the European Union 2016a, p. 9). According to the European Economic and Social Committee "remuneration" could include some elements that are not included in the concept of "minimum rate of pay", such as seniority allowances, allowances and supplements for dirty, heavy or dangerous work, quality bonuses, $13^{\text {th }}$ month bonuses, travel expenses and meal vouchers (European Economic and Social Committee 2017, p. 84; Council of the European Union 2017, p. 3). In this context the Commission's proposal refers to the court ruling of the ECJ in the case of Elektrobudowa (judgement of the ECJ, Elektrobudowa, C-396/13). Here it was stated that the minimum holiday pay which the posted worker must receive for the minimum period of paid annual leave corresponds to the minimum wage (paras. 64-69). Furthermore, daily allowances and compensations for daily travelling timethat is not paid to the workers in reimbursement of expenditure actually incurred on account of the posting -i.e. it is granted on a flat-rate basis (as it isaccording to Austrian law) - are to be regarded as part of the minimum wage (paras. 46-52 and 53-57). However,

3 This extension was initiated by the Slovak Presidency, which proposed to insert "conditions of collective accommodation for workers" to the hard nucleus in order to guarantee equivalent conditions for posted and local mobile workers. Thus, it would have been ensured that the standard of accommodation arranged by an employer for posted workers is equivalent to the standard of accommodation for local mobile workers guaranteed by national law or practice, provisions relating to collective accommodation. Recitals would provide that posted workers may be required to pay rent for their accommodation (Council of the European Union 2016c, 14368/16). 
accommodation costs and meal vouchers, which serve to reimburse the cost of living actually incurred as a result of posting, cannot be counted towards the minimum wage in view of the purpose of Art. 3 para. 7 (paras. 58-60 and 61-63). In case of doubt - i.e. if the reimbursement rules do not stipulate which elements of the allowance are allocated to the reimbursement of expenditure incurred on account of the posting and which are part of remuneration - the entire allowance should be considered to be paid in reimbursement of expenditure and can therefore not be taken into account when it comes to a comparison of the remuneration of the sending state and the host state (Art. 3 para. 7 subpar. 3 and recital 20).

The ECJ refers to past case law (judgement of the ECJ, Kommission/Deutschland, C-341/02; judgement of the ECJ, Isbir, C-522/12) where it was stated that allowances and supplements paid by an employer which alter the relationship between the service provided by the worker and the payment which he receives, are not to be recognised as constituent elements of the minimum wage. With this in mind, $13^{\text {th }}$ and $14^{\text {th }}$ month bonuses such as Christmas and holiday allowances change the relationship just as little as age-related advances (in accordance with the principle of ancestry), whereas dirt and hardship allowances change the counter-performance ratio, since they pursue a different purpose (crit.: Windisch-Graetz 2015). Whether lump sum payments can be taken into account in determining the minimum wage depends on the intention of the parties of the collective agreement to introduce an increase in wages in consideration of the work or to pursue an objective of social policy such as the formation of a capital amount that the worker will benefit from in the longer term (judgement of the ECJ, Isbir, C-522/12, paras. 40-44). Annual bonuses usually do not alter the consideration ratio and can therefore be counted towards the minimum wage. The clarification provided in the current Austrian Government Program for 2017 to 2022 that annual bonuses should be counted towards any wage dumping during the year could be implemented by law also in the light of the new PWD (see $\$ 13$ (4) last sentence and $\$ 29$ (1) third and fourth sentence LSD-BG; also: Schrank 2017a, 2017b; Wiesinger 2017, p. 60). After all, the PWD does not comment on the reference period, but rather refers to the national rules which should apply equally to nationals and posted workers.

Since the Austrian Act on wage and social dumping control (Gesetz zur Bekämpfung von Lohn- und Sozialdumping - LSD-BG), which has transposed the obligations laid down in the PWD and the Enforcement Directive, already deals with the broad concept of pay (i.e. including allowances, surcharges, special payments etc.), this codification of ECJ case law is unlikely to require any national implementation. Conversely, the scope for the measure of mitigation provided for in the current Austrian government programme for 2017 to 2022, namely "maintaining the concept of pay for the construction sector that is mainly affected, otherwise examination of the de-bureaucratisation by limiting basic salary plus special payments", appears to be clearly limited. Apart from that, according to $\$ 3$ (3) LSD-BG, which regulates the minimum wage claim of workers posted to Austria, contributions according to $₫ 6$ Federal Act on Corporate Staff and Self-Employment Provision (Betriebliche Mitarbeiter- und Selbstständigenvorsorgegesetz, BMSVG) as well 
as contributions according to the Company Pension Act (Betriebspensionsgesetz, BPG) are excluded from the concept of remuneration. While the exclusion of contributions according to BPG, that constitute complementary occupational pensions, finds coverage in the new PWD for both short-term and long-term posting (Art. 3 para. 3 lit. c and para. 1a subpar. 2 lit. b), the question arises whether contributions according to $₫ 6 \mathrm{BMSVG}$, that constitute severance pay in case of termination of employment, can also be exempted. After all, the severance pay serves primarily the bridging support between two employment relationships; the additional function of supplementary old-age provision is merely subsidiary (see also: Glowacka 2013a, p. 305; Ritzberger-Moser 2012, p. 24-25).

\section{Long-term posting}

The PWD 96/71/EC does not provide a clearly defined limit with regard to the duration of the posting, but rather focuses on the return and readmission of the contracting parties. The criteria for the continuation of the employment relationship and the close ties to the posting company have been used (Burger 2010). The time limit according to Art. 12 Regulation on the coordination of social security systems (OJ L 2004/166 of 29 April 2004 , p. 1) set at 24 months only provided an indication of the delimitation between short-term and long-term postings (Glowacka 2013b; judgement of the ECJ, Schlecker, C-64/12, paras. 40-43). Article 4 Enforcement Directive lists criteria that should facilitate the identification of whether a person can be subsumed under the definition of a posted worker. The Commission's original proposal had provided for the host Member State to become the place where the work is habitually carried out in the event that the posting exceeds 24 months (Art. 2a). Thus, an individual employment contract would be governed by the employment law of the host Member State according to Art. 8 Rome I Regulation (European Committee of the Regions 2017, p. 75), unless the parties have agreed to the application of another law in accordance with Art. 3 of the Rome I Regulation (Council of the European Union 2016a, p. 6; 2016b, p. 5). In the latter case, only the more favourable mandatory provisions of the host country that cannot be deviated from by agreement would apply, including collective agreements and works council agreements, provided that the general conditions of application of those agreements (e.g. $\$ 36$ of the Austrian Labour Constitution Act, Arbeitsverfassungsgesetz - ArbVG) are met (Martiny 2015, para. 34; Pfeil 2008, p. 7).

Now, according to the new Art. 3 para. 1a, a clear time limit has been set. If the effective duration of postings exceeds 12 months, workers will be deemed to be posted long-term. For an extension to 18 months, it is sufficient to submit a motivated notification. The reason given for this limitation is the link between the labour market of the host Member State and the long-term posted worker (recital 9). In order to exclude circumvention of this time limit, the duration of the posting must be cumulated if a posted worker is replaced by another posted worker carrying out the same task at the same place (European Economic and Social Committee 2017, p. 86). With regard to Art. 1 para. 3, it can be assumed that a temporary agency worker can replace a posted 
worker in the stricter sense and vice versa. The relevant recital seems to focus on whether the replacement was the reason for posting in the first place (recital 11). Apart from that, it is questionable whether in the case of a non-fluent transition - i.e. either an overlap or a staggered posting of the second worker in comparison to the return of the first worker - the term replacement is still valid. It is striking that, with regard to the principle of proportionality, the Commission's proposal sought to apply the consequences of the accumulation of the posting period only to workers who had been posted for at least 6 months. Conversely, the Commission's proposal provided that the "planned", i.e. expected, period of posting already triggered the consequences of long-term postings. This was dropped again in view of the associated legal uncertainty. Apart from that, the compatibility of such a scheme with the basic principles of the Single European Market would be highly questionable. No explicit regulation has been stipulated in case of an interruption of the posting of a worker and whether it shall be deemed a continuous posting or two independent postings, both triggering different consequences. In the discussions on the Commission proposal, the Council referred in this context to Regulation 883/2004 (Council of the European Union 2016a, p. 5).

In this case, a fresh period of posting within the meaning of Art. 12 of Regulation $883 / 2004$ for the same worker, the same undertakings and the same Member State can be authorised until at least two months have elapsed from the date of expiry of the previous posting period (The Administrative Commission for the Coordination of Social Security Systems 2010, para. 3 lit. c). Thus, in the case of a two-month interruption, at any rate, there are two independent postings.

In case of long-term postings according to Art. 3 para. 1a, that is where the effective duration of a posting exceeds 12 (or 18) months, Member States shall ensure that not only the hard nucleus has to be applied to the posted worker but all applicable terms and conditions of employment of the host Member State (but for supplementary occupational retirement pension schemes and procedures, formalities and conditions of the conclusion and termination of the employment contract, including non-competition clauses) (Council of the European Union 2016c, p. 4). In view of the fact that the wording of the new PWD differs from the Commission's proposal and there is no longer any talk of a change of the applicable employment law, it must be questioned whether the consequences are the same or whether the new Art. 3 para. 1a implies less than the Commission's proposal. In the case of De Clercq, the ECJ (judgement of the ECJ, C-315/13, paras. 42-48) found that monitoring measures necessary to ensure compliance do not fall within the scope of the PWD and are not to be considered as terms and conditions of employment. A narrow interpretation of "terms and conditions of employment" is supported by the balance between fair competition and employee protection as intended by the Directive. For example, in recital (10) there is talk of the protection of workers being limited by the freedom to provide services, because even in the case of long-term postings, companies still have the right to invoke it. The application of the specific terms and conditions of employment must be examined for compatibility with ensuring freedom to provide services. According to settled case law (judgement of the ECJ, Guiot, 
C-272/94, para. 11; judgement of the ECJ, Arblade, C-369/96 and C-376/96, para. 35), restrictions on the freedom to provide services are justified by overriding requirements relating to the public interest as long as they meet the requirements of proportionality (judgement of the ECJ, Kommission/Luxemburg, C-319/06, para. 42).

Just as the elements making up the remuneration, the other terms and conditions of employment to be respected in the case of short-term and long-term postings - rendered mandatory by national law, regulation or administrative provision, or by collective agreements or arbitration awards which have been declared universally applicable or otherwise generally binding in accordance with para. 8 - must also be published on the website already established under Art. 5 Enforcement Directive. All information must be published on a single official national website. In order to meet this requirement with regard to all collective agreements valid in Austria, in my opinion a linked reference to the existing database(s) is sufficient; an additional obligation appears to be excessive. The circumstance of inadequate or incomplete information shall be taken into account when determining the penalties applicable in the event of infringement of (recital 21).

In any case, these changes with regard to long-term postings introduced by the amending Directive require national implementation in Austria, as the applicable LSDBG - with the exception of $\$ 1$ (5) and (6) - does not differentiate between short-term and long-term postings. When it comes to continuity of remuneration to employees in the event of illness or on other grounds that justify continued payments by the employer, the rules according to the Austrian Continued Payment of Remuneration Act (Entgeltfortzahlungsgesetz, EFZG) and the Employees Act (Angestelltengesetz, AngG) remain excluded from the terms and conditions of employment that have to be applied to posted workers (judgement of the ECJ, Paletta, C-45/90; Pfeil 2015, p. 99; Rebhahn 2015a; Sozial Ministerium 2015). However, it should be noted that $\$ 6$ (1) LSD-BG, which entitles temporary agency workers to sick pay in the event of sickness or accident including termination of employment, public holidays and leave for other important personal reasons in the amount valid for comparable workers, applies to cross-border temporary agency workers being classified as an overriding mandatory provision within the meaning of Art. 9 Rome I Regulation.

Conversely, the regulations of the Austrian Employment Liability Act (Dienstnehmerhaftpflichtgesetz, DHG) will probably have to be subsumed under the new Art. 3 para. 1a PWD. The liability reliefs that are securitized here, are to be assigned to employment law, and serve to protect employees (against transferral of operating risks, to which certain damages are attributable) and affect the relationship between employers and employees (Windisch-Graetz 2018a). In my opinion, the new Art. 3 para. 1a also includes the terms and conditions of employment standardized by the Austrian Labour Constitution Act (Arbeitsverfassungsgesetz, ArbVG) that serve as a means to the protection of the individual interests of employees, provided that the general conditions of application are fulfilled (in particular integration into the company of the host Member State pursuant to $\$ 36$ ArbVG) (Windisch-Graetz 2018b). If the integration into the company is accompanied by a transfer of the essential employer functions, an overall assessment of the criteria 
standardized in $\$ 4$ (2) Temporary Agency Work Act (Arbeitskräfteüberlassungsgesetz, AÜG) will usually be in favour of temporary employment work. Temporary agency workers are considered to be integrated into the company of the user undertaking after 6 months at the latest (Geppert 1991; Tomandl 2017).

Although conceived as a collective legal instrument, the protection against unfavourable transfers within the meaning of $\$ 101$ ArbVG also has an individual protective function under labor law since it provides employees with another protection mechanism that grants works councils a veto (Schneller 2006, p. 1018). Bearing in mind an integration into the receiving company or the user undertaking, both the works council of the posting company as well as the works council of the receiving company can be deemed responsible. Two constellations can be distinguished: return and "chain posting". While the decision to ask the worker to return after a long-term posting will normally be to the foreign employer, the relocation within the meaning of the new subpara. of Art. 1 para. 3 lit. c (i.e. chain posting) is based on the decision of the domestic employer or user undertaking. Upon fulfillment of the general conditions of application, the right to co-operate within the meaning of $₫ 101$ ArbVG shall be assigned to the domestic works council, provided that the assignment of the chain posting represents a transfer from the perspective of the receiving domestic company. From the user undertaking's point of view, the return does not usually have the character of a transfer, which is why the powers of participation provided for in $\$ 101$ ArbVG do not belong to the domestic works council (compare for an Austrian perspective: Schrattbauer 2015, p. 186-191). A referral to a foreign works council - if such has been set up at all - seems incompatible with the principle of territoriality (in general: Strasser 1988).

As already mentioned, under Art. 3 para. 1a subpar. 2, "procedures, formalities and conditions for the conclusion and termination of the employment contract, including non-compete obligations" (lit. a) and "supplementary occupational pension schemes" (lit. b) are explicitly excluded from the catalogue of terms and conditions of employment (Commission of the European Communities 1991). Employment bans or conditions according to the Austrian Children and Adolescents Employment Act (Kinder- und Jugendlichen-Beschäftigungsgesetz, KJBG) as well as the Disability Employment Act (Behinderteneinstellungsgesetz, BeinstG) and the Vocational Training Act (Berufsausbildungsgesetz, BAG) can be understood as regulations for the conclusion of the employment contract. Otherwise, the question would be raised as to whether employers, who send a larger number of employees to Austria, would have to pay a compensation tax within the meaning of $₫ 9$ BeinstG as compensation for not employing disabled people. The obligations resulting from the pre-contractual obligation (mutual interest-preservation obligations) could also be subsumed here, as well as the minimum content of the basic employment contract or inadmissible contractual provisions standardized in $\$ 11$ AÜG. In particular, the exemption of formal requirements appears to be sensible in order to maintain agreements reached in force (e.g. agreement store imburse training costs) (see: $\$ 2 \mathrm{~d}$ of the Employment Contract Law Amendment Act; ArbeitsvertragsrechtsAnpassungsgesetz, AVRAG). Of particular importance is the exemption of regulations 
on termination of the employment contract. This may include the applicable notice periods and deadlines, dismissal protection as well as termination-dependent claims of comparable employees (e.g. indemnity for untimely termination, so-called job-seeking days) (see: $\$ 22$ of the Employees Act (Angestelltengesetz, AngG) and $₫ 1160$ of the Austrian General Civil Code (Allgemeines bürgerliches Gesetzbuch, ABGB)).

\section{Temporary agency workers}

Apart from terminological adjustments in Art. 1 para. 3 lit. c, a provision has been stipulated for successive postings of temporary agency workers in a new subpara. According to this, temporary agency workers shall be considered posted by the temporary employment undertaking if they have to carry out work by the user undertaking in another Member State than where they normally work for the temporary employment undertaking or the user undertaking; e.g.temporary employment undertaking in Poland assigns temporary agency workers to a user undertaking in Austria by whom they are temporarily being posted to Hungary. Since, in this situation, the temporary employment undertaking (PL) has to apply the more favourable terms and conditions of employment of the other Member State (HUN), the user undertaking (Ö) shall inform the temporary employment undertaking $(\mathrm{PL})$ in due time before commencement of the posting (see recital 13).

In addition, Art. 3 para. $1 \mathrm{~b}$ regulates that the principle laid down in Art. 5 of the Temporary Agency Work Directive 2008/104/EC (TAD) (OJ L 2008/327 of 19 November 2008, p. 9) should also apply to cross-border workers. This principle of equal treatment stipulates that the basic terms and conditions of employment of temporary agency workers shall be, for the duration of their assignment at a user undertaking, at least those that would apply if they had been recruited directly by that undertaking to occupy the same job. According to Art. 3 para. 1 lit. fTAD, basic working and employment conditions means working and employment conditions laid down by legislation, regulations, administrative provisions, collective agreements and/or other binding general provisions in force in the user undertaking relating to the duration of working time, overtime, breaks, rest periods, night work, holidays, public holidays and pay (Rebhahn, Schörghofer 2018; Schlitzer 2013, p. 10f).

According to the explanations provided by the Commission (European Commission 2016b, p. 9), this new paragraph corresponds to the original Art. 3 para. 9 - which is why it could have been omitted according to the Commission - with the difference that this is now a legal obligation imposed on Member States rather than a derogation (comp.: European Economic and Social Committee 2017, p. 87). Where that principle applies, the user undertaking should inform the temporary employment undertaking about the working conditions and remuneration it applies to its workers. However, there is no obligation to provide information if - in accordance to Art. 5 para. 2 and 3 of the Temporary Agency Work Directive - use was made of the derogation from the principle of equal treatment or equal pay (recital 12). Contrary to the original Commission's proposal, Art. 3 para. 9 allows Member States to specify that more favourable working 
conditions than those laid down in Art. 5 of the Temporary Agency Work Directive should apply to cross-border temporary agency workers. This will allow for full equal treatment of posted and local temporary agency workers.

While the obligation to provide information within the meaning of Art. 1 para. 3 lit. $c$ requires national transposition, the equal treatment of cross-border and national temporary agency workers within the meaning of Art. 3 para. $1 \mathrm{~b}$ in conjunction with Art. 5 TAD seems to be guaranteed in Austria.

\section{Enforcement}

It is noteworthy that although an amendment to Art. 5 was neither part of the Commission's proposal nor the general approach of the Council, the changes initiated by the Employment Committee of the Parliament in the trilogue negotiations prevailed.

To date, the PWD has only required Member States to take appropriate measures in the event of failure to comply with this Directive and to ensure that adequate enforcement procedures are available. Therefore, it was argued in the literature that the Directive did not authorise the Member States to criminalise undertakings that did not meet the minimum standards (Felten 2011, p. 407-408; Schrank 2017c). This can be supported by the fact that the PWD has not mentioned penalties so far - as opposed to other Directives, e.g. Art. 10 Temporary Agency Work Directive. According to Rebhahn (Rebhahn 2018b), not even the Enforcement Directive obliges Member States to provide for sanctions in the event of non-compliance. After all, Art. 20 of the Enforcement Directive requires sanctions only if this Directive is infringed, but not the PWD itself. On the contrary, it is emphasized that all the measures introduced by this Directive should be justified and proportionate so as not to create administrative burdens or to limit the potential that undertakings, in particular small and medium-sized enterprises (SMEs), have to create new jobs, while protecting posted workers (recital 4). Nonetheless, Heuschmid/Schierle (Heuschmid, Schierle 2015) believe that effective, dissuasive and proportionate sanctions can be part of the measures under Art. 5. It is true that the ECJ (judgement of the ECJ, Wolff \& Müller, C-60/03, para. 30) has granted the Member States a wide margin of appreciation in determining the form and detailed rules governing the adequate procedures under Art. 2 para. 2 (limited only by the fundamental freedoms freedoms guaranteed by the Treaty) (Kullmann 2015, p. 44). As para. 2 of this article describes procedures available to workers and/or their representatives for the enforcement of obligations under the PWD, to my mind sanctions may be subsumed under para. 1 only (Tscherner 2012, p. 265). So far, the Austrian legislator could have been accused of having committed so-called gold plating with regard to the partly exorbitant penalties of the LSD-BG (Glowacka 2018, p. 217).

It has now been clarified in the new wording of Art. 5 that the sending and the host Member States shall be responsible for the monitoring, control and enforcement of the obligations laid down in the PWD and the Enforcement Directive. In addition, Member States must provide for penalties, which shall be effective, proportionate and 
dissuasive (Bobek 2018, paras. 180 and 190). As already mentioned, the current Austrian government program for 2017 to 2022 provides for some measures concerning the Austrian Act on wage and social dumping control (LSD-BG), which has implemented the obligations laid down in the PWD and the Enforcement Directive. Thus, the "fight against wage and social dumping should be clearly focused on genuine cases of wage dumping and at the same time the bureaucracy burden for businesses generally reduced". Insofar as a possible mitigation of the measures provided for in the LSD-BG has been considered, it is now questionable whether this is still an option in sight of the new wording of Art. 5. Moreover, it might become necessary to bring in line the wording of $\$ \$ 3$ and 29 LSD-BG. This deals with the right to the same remuneration of posted and national workers on the one hand and the sanctions in case of non-compliance with this obligation on the other hand; seeing as the latter makes some exemptions to the concept of remuneration while the former does not (Schrank 2017d).

Apart from that, Member States have to ensure that in the case of so-called non-genuine postings - that is, if the overall assessment made pursuant to Art. 4 Enforcement Directive shows that an undertaking is improperly or fraudulently creating the impression that the situation of a worker falls within the scope of this Directive - the worker benefits from relevant law and practice. However, this must not result in workers being subject to less favourable conditions than those applicable to posted workers. In order to counteract bogus and law-evading transactions, the Austrian LSD-BG had already pre-empted the PWD and securitized the principle of true economic content in $₫ 2$, which provides a standard of assessment following other labour law, tax or social security law provisions such as $\$ 2$ AuslBG, $\$ 4$ AÜG, $\$ 21 \mathrm{BAO}, \S 67$ (8) ASVG, $\$ 539 \mathrm{a}(1)$ ASVG.

\section{Conclusion}

The revision of the PWD, finalized in summer 2018, introduces some changes, some of which go beyond what was proposed by the Commission in 2016. Partly the new PWD resharpens existing provisions and codifies some of the case law of the ECJ. From an Austrian perspective, for the most part, these revised provisions do not require national implementation. Nevertheless, the scope for some of the measures of mitigation provided for in the current Austrian government programme for 2017 to 2022 appears to be limited. Furthermore, the revised PWD sets a clear time limit to short-term postings that does not follow the example set by the Regulation on the coordination of social security systems since the limit according to the PWD is set at 12 (or 18) months, not 24 months as proposed by the Commission. Since exceeding this limit shall result in the obligation to apply all terms and conditions of employment of the host Member State (aside from supplementary occupational retirement pension schemes and procedures, formalities and conditions of the conclusion and termination of the employment contract, including non-competition clauses), one of the most important issues with regard to national implementation concerns the scope of these terms and conditions as well as these derogations. 


\section{References}

Aubauer H., Glowacka M. (2019) EntsendeRL neu [in:] C. Kietaibl, R. Mosler, H. Pacic, Gedenkschrift Robert Rebhahn, Wien, p. 1-20.

Burger F. (2010) Para. 16.05. [in:] G.P. Reissner, M. Neumayr, Zeller Handbuch ArbeitsvertragsKlauseln, Wien, p. 224-225.

Felten E. (2011) Maßnahmen zur Einhaltung der Mindestlohnbedingungen nach dem neuen Lohn- und Sozialdumping-Bekämpfungsgesetz, "Wirtschaftsrechtliche Blätter", Vol. 25, Issue 8, p. 405-413.

Geppert W. (1991) OGH 13.2.1991, 9 Ob A 22/91, “Das Recht der Arbeit”, H. 42, p. 352.

Glowacka M. (2013a) Betriebspension bei grenzüberschreitendem Arbeitnehmereinsatz, "ASoK. Arbeits- und Sozialrechtskartei”, 2013, p. 300.

Glowacka M. (2013b) Para. 9.10 [in:] M. Drs (Hrsg.), Handbuch Betriebspensionsrecht, Wien, p. $248-249$.

Glowacka M. (2018) LSD-BG: Bisherige Erfahrungen aus der Judikatur, "Zeitschrift für Arbeitsund Sozialrecht", H. 4, p. 212.

Heuschmid J., Schierle F. (2015) § 5 para 190 [in:] U. Preis, A. Sagan, Europ AR, Köln.

Kullmann M. (2015) Enforcement of Labour Law in Cross-Border Situations, Deventer, p. 44.

Martiny D. (2015) Art 8 Rom I-VO para 34 [in:] F.J. Säcker, R. Rixecker, H. Oetker (Hrsg.), MünchKomm $X^{6}$, München.

Pfeil W.J. (2008) Grenzüberschreitender Einsatz von Arbeitnehmern (Teil I) (FN 1), "Das Recht der Arbeit", p. 3.

Pfeil W.J. (2015) [in:] S. Urnik, W.J. Pfeil, Internationale Personalentsendungen, Wien, p. 99.

Rebhahn R. (2018a) 460 Art 3 para 29 [in:] M. Franzen, I. Gallner, H. Oetker, Europ AR², München, p. 1160.

Rebhahn R. (2018b) 460 Art 5 para 4 [in:] M. Franzen, I. Gallner, H. Oetker, Europ AR², München, p. 1168.

Rebhahn R., Schörghofer F. (2018) 620 Art 3 para 11 [in:] M. Franzen, I. Gallner, H. Oetker, Europ $A R^{2}$, München, p. 2187.

Risak M. (2016) Die Dinge anders angehen?, "Das Recht der Arbeit”, H. 4, p. 306.

Ritzberger-Moser A. (2012) Rechtspolitischer Hintergrund und geplante Änderungen [in:] M. Drs, Abfertigungsrecht, Wien, p. 23-30.

Schlitzer A. (2013) Die Umsetzung der Leiharbeitsrichtlinie, infas, p. 9.

Schneller H. (2006) Arbeitskräfteüberlassung: Mitbestimmung bei Versetzungen und anderen personellen Maßnahmen, “ecolex”, H. 12, p. 1018.

Schrank F. (2017a) LSD-BG $\$ 3$ para. 10 [in:] F. Schrank, V. Schrank, M. Lindmayr, Lohn- und Sozialdumping-Bekämpfungsgesetz: Kommentar, Wien, p. 56.

Schrank F. (2017b) LSD-BG $\$ 29$ para 73 [in:] F. Schrank, V. Schrank, M. Lindmayr, Lohn- und Sozialdumping-Bekämpfungsgesetz: Kommentar, Wien, p. 440.

Schrank F. (2017c) LSD-BG \$29 para 26 [in:] F. Schrank, V. Schrank, M. Lindmayr, Lohn- und Sozialdumping-Bekämpfungsgesetz: Kommentar, Wien, p. 423. 
Schrank F. (2017d) LSD-BG $\$ 3$ para 25 [in:] F. Schrank, V. Schrank, M. Lindmayr, Lohn- und Sozialdumping-Bekämpfungsgesetz: Kommentar, Wien, p. 60.

Schrattbauer B. (2015) Arbeitskräfteüberlassung, Wien, p. 186 - 191.

Strasser R. (1988) \$ 33 Anm 4 [in:] H. Floretta, R. Strasser, ArbVG, Wien, p. 197.

Tomandl T. (2017) \$ 36 para 11 [in:] T. Tomandl, ArbVG, Wien, p. 9-10.

Tscherner E.M. (2012) Arbeitsbeziehungen und Europäische Grundfreiheiten, Köln, p. 265.

Wiesinger C. (2017) Der Durchrechnungszeitraum beim Lohn- und Sozialdumping, "ASoK. Arbeits- und Sozialrechtskartei”, p. 6064.

Windisch-Graetz M. (2015) Anspruch auf und Durchsetzung von Mindestlöhnen bei grenzüberschreitenden Entsendungen, "Das Recht der Arbeit", H. 6, p. 508-515.

Windisch-Graetz M. (2018a) \& 1 DHG para 1 [in:] M. Neumayr, G.P. Reissner, ZellKomm³. Band 1, Wien, p. 1872.

Windisch-Graetz M. (2018b) \$ 36 ArbVG para 4 [in:] M. Neumayr, G.P. Reissner, ZellKomm³. Band 2, Wien, p. 153.

\section{Legal acts}

OJ L 1997/18, p. 1-6. Directive 96/71/EC of the European Parliament and of the Council of 16 December 1996 concerning the posting of workers in the framework of the provision of services.

OJ L 2004/166, p. 1-123. Regulation (EC) No 883/2004 of the European Parliament and of the Council of 29 April 2004 on the coordination of social security systems.

OJ L 2008/327, p. 9-14. Directive 2008/104/EC of the European Parliament and of the Council of 19 November 2008 on temporary agency work.

OJ L 2014/159, p. 11-31. Directive 2014/67/EU of the European Parliament and of the Council of 15 May 2014 on the enforcement of Directive 96/71/EC concerning the posting of workers in the framework of the provision of services and amending Regulation (EU) No 1024/2012 on administrative cooperation through the Internal Market Information System ("the IMI Regulation").

OJ L 2018/173, p. 16-24. Directive (EU) 2018/957 of the European Parliament and of the Council of 28 June 2018 amending Directive 96/71/EC concerning the posting of workers in the framework of the provision of services.

\section{Court sentences}

Judgement of the ECJ. Rush Portuguesa. C-113/89 (27 March 1990). ECLI:EU:C:1990:142. Judgement of the ECJ. Paletta. C-45/90 (3 June 1992). ECLI:EU:C:1992:236. Judgement of the ECJ. Guiot. C-272/94 (28. March 1996). ECLI:EU:C:1996:147. Judgement of the ECJ. Arblade. C-369/96 and C-376/96 (23 November 1999). ECLI:EU:C:1999:575. Judgement of the ECJ. Wolff \& Müller. C-60/03 (12 October 2004). ECLI:EU:C:2004:610. Judgement of the ECJ. Kommission/Deutschland. C-341/02 (14 April 2005). ECLI:EU:C:2005:220. Judgement of the ECJ. Kommission/Luxemburg. C-319/06 (19 June 2008). ECLI:EU:C:2008:350. 
Judgement of the ECJ. Schlecker. C-64/12 (12 September 2013). ECLI:EU:C:2013:551.

Judgement of the ECJ. Isbir. C-522/12 (7 November 2013). ECLI:EU:C:2013:711.

Judgement of the ECJ. De Clercq $i$ in. C-315/13 (3 December 2014). ECLI:EU:C:2014:2408.

Judgement of the ECJ. Elektrobudowa. C-396/13 (12 February 2015). ECLI:EU:C:2015:86.

\section{Documents and authorities' opinions}

Bobek M. (2018) Opinion of Advocate General. C-193/17 (25 July 2018). ECLI:EU:C:2018:614. Commission of the European Communities (1991) COM (91) 230 final - SYN 346. Brussels (1 August 1991).

Council of the European Union (2016a) 7894/16. Brussels (22 April 2016).

Council of the European Union (2016b) 11529/16. Brussels (27 July 2016).

Council of the European Union (2016c) 14368/16. Brussels (25 November 2016).

Council of the European Union (2017) 9882/17. Brussels (9 June 2017).

Council of the European Union (2018) 9383/18. Brussels (15 June 2018).

European Commission (2016a) Commission Staff Working Document: Impact Assessment. $\operatorname{SWD}(2016) 52$ final.

European Commission (2016b) Proposal for a Directive of the European Parliament and of the Council amending Directive 96/71/EC of The European Parliament and of the Council of 16 December 1996 concerning the posting of workers in the framework of the provision of services. COM(2016) 128 final, 9. Strasbourg (8 March 2016).

European Committee of the Regions (2017) Opinion: The Revision of the Posting of Workers Directive of 9.06.2017. OJ C 2017/185, p. 75-81.

European Economic and Social Committee (2017) Opinion on the 'Proposal for a Directive of the European Parliament and of the Council amending Directive 96/71/EC of the European Parliament and of the Council concerning the posting of workers in the framework of the provision of services' of 10.03.2017. OJ C 2017/75, p. 81-96.

European Parliament (2018) Fact Sheets on the European Union: Working in the European Union. PE 600.417.

Sozialministerium (2015) LSDB-Richtlinien 2015. GZ BMASK-462.203/0006-VII/B/9/2015.

The Administrative Commission for the Coordination of Social Security Systems (2010) Decision No A2 of 12 June 2009 concerning the interpretation of Article 12 of Regulation (EC) No 883/2004. CJ C 2010/106, p. 5-8. 